\title{
Validation of Nitrogen and Phosphorus Fertilizers Application Rates for Maize (Zea mays L.) in Yeki District, Southwest of Ethiopia
}

\author{
Mulisa Wedajo*, Shiferaw Temteme, Guta Amante, Beniam Yaziz \\ Teppi Agricultural Research Center, Teppi, Ethiopia \\ Email address: \\ mulisawedajo@gmail.com(M. Wedajo), shiferawtemteme@yahoo.com (S. Temteme), gutiyye@gmail.com (G. Amante), \\ beniamyaziz@gmail.com (B. Yaziz) \\ ${ }^{*}$ Corresponding author
}

To cite this article:

Mulisa Wedajo, Shiferaw Temteme, Guta Amante, Beniam Yaziz. Validation of Nitrogen and Phosphorus Fertilizers Application Rates for Maize (Zea mays L.) in Yeki District, Southwest of Ethiopia. Agriculture, Forestry and Fisheries. Vol. 10, No. 1, 2021 , pp. 16-20. doi: $10.11648 /$ j.aff.20211001.13

Received: November 12, 2020; Accepted: November 23, 2020; Published: March 10, 2021

\begin{abstract}
Maize (Zea mays L.,) is an important smallholder crop grown in Ethiopia. Its yields are low because of a decline in soil fertility, insufficient use of fertilizers, and blanket use of fertilizer. However, there is no Nitrogen and Phosphorus fertilizer recommendation for Maize in Yeki District. A three-year field experiment was conducted to verify the effects of nitrogen and phosphorus fertilizer rates for maize. The experiment consisted of three treatments; $92 \mathrm{~kg} \mathrm{~N} \mathrm{ha}^{-1}+69 \mathrm{~kg} \mathrm{P}_{2} \mathrm{O}_{5}$ ha ${ }^{1}, 64 \mathrm{Kg} \mathrm{N} \mathrm{ha}^{-1}+46 \mathrm{~kg} \mathrm{P}_{2} \mathrm{O}_{5}$ ha $^{-1}$ and no fertilizer (control) laid out using a randomized complete block design with four replications. The replication represents the four locations selected for the test. The results of the study showed that the application of $92 \mathrm{~kg} \mathrm{~N} \mathrm{ha}^{-1}+69 \mathrm{~kg} \mathrm{P}_{2} \mathrm{O}_{5}$ ha $^{-1}$ significantly increased the growth parameters and yield of maize when compared to the other treatments. The highest maize grain yield $\left(10052.9 \mathrm{~kg} \mathrm{ha}^{-1}\right)$ was obtained from the application of $92 \mathrm{~kg} \mathrm{~N}^{-1}$ with $69 \mathrm{~kg} \mathrm{P}_{2} \mathrm{O}_{5} \mathrm{ha}^{-1}$. This study further confirms the significant role of nitrogen and phosphorus fertilizers for maize production. From the result of the study, the application rate of $92 \mathrm{~kg} \mathrm{~N} \mathrm{ha}^{-1}+69 \mathrm{~kg} \mathrm{P}_{2} \mathrm{O}_{5} \mathrm{ha}^{-1}$ is recommended for increasing maize yield, particularly in the study area, and also it is economically feasible.
\end{abstract}

Keywords: Blanket Recommendation, Nitrogen, Phosphorus and Yield

\section{Introduction}

Poor soil fertility is recognized as the major constraint to food production and food security in the world. The problem might be more in the case of developing countries like Ethiopia, due to high population density, fragmented farmland as well as continues farming and untailored fertilizer application. Ethiopia has potentially rich land resources but agricultural productivity has been below optimum yield. This is mainly due to a range of factors including soil erosion, acidity and nutrient depletion, lack of soil fertility replenishment, nutrient mining, and lack of balanced fertilization [1-3]. Crop yield tends to decrease when the soil gets depleted of its nutrients. The proper rates of plant nutrients requirements are determined by knowledge about; the nutrient requirement of the crop and supplying capacity power of the soil.

Maize (Zea mays L.,) is an important cereal crop grown in Ethiopia as well as in the Yeki area [4]. The greatest potential for maize production is fully realized with adequate fertilizer application. Nitrogen and Phosphorus fertilizer recommendations are determined for maize in different agroecology of Ethiopia. For instance, in Southern West Ethiopia, farmers apply $100 \mathrm{~kg}$ ha-1 both DAP and Urea for maize irrespective of the heterogeneity of the farm areas. However, there is no fertilizer recommendation rate for maize production in Yeki District. The present study aimed at validating the NP fertilizer rate recommended for maize (92 $\mathrm{N}$ and $\left.69 \mathrm{P}_{2} \mathrm{O}_{5}\right) \mathrm{kg} \mathrm{ha}^{-1}$ Wakene et al., [5] at Oromia Region on Nitisol of Jimma District to SNNPR state at Yeki District (Figure 1). 


\section{Materials and Methods}

\subsection{Description of the Study Area}

The study was carried out in Yeki District Sheka zone of the SNNPR state (Figure1). The mean annual rainfall of the area is $1559 \mathrm{~mm}$ that extends from April to December, with hot to warm humid lowland agro-ecology. The maximum and minimum average temperatures of the area are $29.7^{\circ} \mathrm{C}$ and $15.5^{\circ} \mathrm{C}$, respectively.

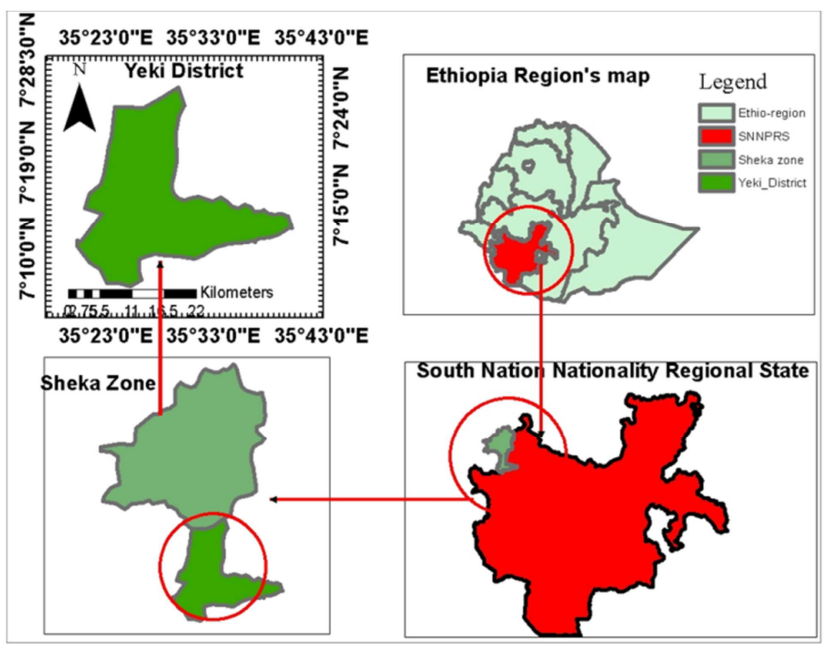

\subsection{Experimental Materials}

A high yielding medium maturing hybrid maize variety (BH140) was used as a test crop. It performs well at an altitude range of 1000-1800 m.a.s.1 with rainfall of 1000$1200 \mathrm{~mm}$. It can give (7.5-8.5 and 4.7-6) $\mathrm{t} \mathrm{ha}^{-1}$ grain yields on-station and on-farm experiments respectively with maturity date of 145 and $25 \mathrm{~kg} \mathrm{ha}^{-1}$ seed rate. The nitrogen and phosphorus sources used for the experiment were Urea and Triple Superphosphate (TSP), respectively.

\subsection{Experimental Design and Procedure}

The experiment was laid out in a randomized complete block design with four replication at four locations (Fide, Kubito, Shosha and Teppi on station), those four locations considered as replication. Three treatments (T1: Control, T2: blanket recommendation of $64 \mathrm{~N}$ and $46 \mathrm{P}_{2} \mathrm{O}_{5}$ and $\mathrm{T}$ : $92 \mathrm{~N}$ and $69 \mathrm{P}_{2} \mathrm{O}_{5}$ ) kg ha ${ }^{-1}$ (Table 1) was tested in each location indicated above for three consecutive cropping season of 2017 to 2019 . The area of each plot was $10 \mathrm{~m}$ x $10 \mathrm{~m}$ length and width respectively and then the three treatments were randomly assigned to each experimental unity. The spacing between block and plant were $75 \mathrm{~cm}$ x $25 \mathrm{~cm}$ between row and between plants were used for plating of the maize respectively.

Figure 1. Map of study District.

Table 1. Details of treatment arrangements.

\begin{tabular}{ll}
\hline Treatment codes & Descriptions of treatment code \\
\hline T1 & Control \\
T2 & Blanket recommendation of $64 \mathrm{~N}$ and $46 \mathrm{P}_{2} \mathrm{O}_{5} \mathrm{~kg} \mathrm{ha}^{-1}$ \\
T3 & Recommended NP $\left(92 \mathrm{~N}+69 \mathrm{P}_{2} \mathrm{O}_{5}\right) \mathrm{kg} \mathrm{ha}^{-1}$ \\
\hline
\end{tabular}

Fertilizers' TSP was applied at planting and while urea was applied in twice equal split half at knee height and the remaining half at flag leaf emergence $[6,7]$. The first side dressing was 30 days after emergence (knee height stage) just after the first weeding and again 60 days after emergence just after the second weeding or before tasseling. All other agronomic management practices; land ploughed three times with oxen, time of sowing (early April), seed rate $25 \mathrm{~kg} \mathrm{ha}^{-1}$ and two times hand weeding were applied as per recommendation for the maize production.

\subsection{Data Collection}

Soil: Composited topsoil sample was collected from each experimental site at the depth of $0-20 \mathrm{~cm}$ before sowing. The collected samples air-dried and passed through $2 \mathrm{~mm}$ sieve to remove large particles, debris, and stones. The sieved samples analyzed for $\mathrm{pH}$ in 1:2.5 soils to water ratio using Coleman's pH meter. Organic carbon was determined [8]. Organic matter estimated as organic carbon multiplied by 1.724. Total Nitrogen was determined by the micro Kjeldahl method [9]; available phosphorus was extracted by Bray's II method [9] and read from the atomic absorption spectrometer. The textural analysis was determined by hydrometer method.

\subsubsection{Maize Agronomy}

Plant height $(\mathrm{cm})$ : It was measured as the height from the soil surface to the base of the tassel at maize physiological maturity before harvesting from ten plants sampled randomly from the central rows and summed and divided by the number of plants to get the height of each plant.

Number of ear per plant: was visually counted from a single maize plant of ten randomly sampled from the central rows and summed and divided by the number of plants to get the number of ear of each plant.

Ear height $(\mathrm{cm})$ : It was measured from ground level to the node bearing the top useful ear before harvesting from ten sampled plants randomly from the central rows and summed and divided by the number of plants to get the ear height of each plant.

Thousand grain weight (g): It was determined from 1000 randomly taken grains from each plot and weighed using sensitive balance.

Grain yield $\left(\mathrm{kg} \mathrm{ha}^{-1}\right)$ : Maize crop harvesting was done after the crop had reached physiological maturity. Then, husk was removed and the grains were shelled manually and their weights were recorded by electronic balance. The grain was sun-dried until it had constant weight and reweighed to 
determine moisture content. After drying the grain yield adjusted to $12.5 \%$ moisture content, the final dry weight was determined and recorded and then convert to a hector basis.

\subsubsection{Economic Analysis}

Partial budget and Marginal analysis of economic concepts were used to analyze the data. Partial budget is a method of organizing experimental data and information about the costs and benefits of various alternative treatments. Marginal analysis is a method for comparing the costs that vary with the net benefits for selecting the best technology for recommendations from the experiment.

\subsection{Data Analysis}

The collected data statistically analyzed using the Analysis of Variance (ANOVA) procedures. The treatment means were separated using the Least significant difference) at a 5\% level of probability.

\section{Results and Discussion}

Pre-planting topsoil $(0-20 \mathrm{~cm})$ physical and chemical properties of experimental site during 2017 cropping season were shown in (Table 2). The soils were clay texture in Teppi on-station, Fide and Shosha and clay loam in case of Kubito. The soil texture controls water contents, water intake rates, aeration, root penetration and soil fertility.

Landon [10] provided guidelines for interpreting soil $\mathrm{pH}$ values for environmental evaluation as $\mathrm{pH}>9.0,9.0-8.5$, $8.4-7.9,7.8-7.4,7.3-6.6,6.5-6.1,6.0-5.6,5.5-5,5.0-4.5$ very strongly alkaline, strongly alkaline, moderately alkaline, mildly alkaline, neutral, slightly acid, moderately acid, strongly acid and very strongly acid respectively. Therefore, according to Landon, [10] the soil $\mathrm{pH}$ of Teppi on station was neutral whereas Fide, Kubito and Shosha were slightly acidic. Maize has been found to do well in $\mathrm{pH}$ values of 6.5-8 but the optimum growth is attained at $\mathrm{pH} 5.5-7$ and any $\mathrm{pH}$ below these values will affect its growth.

According to Tekalign and Haque [11] the soil total $\mathrm{N}$ and available $\mathrm{P}$ of all location were high and medium, respectively. Available soil Potassium of the experimental area rated as low (Table 2). Horneck et al. [12] reported that soils with potassium content of $<150 \mathrm{ppm}$ low, 150-250 ppm medium, 250-800 ppm high and $>800 \mathrm{ppm}$ excessive. The Cation Exchangeable capacity of the soil rated as high [10]. The percentage of organic matter and organic carbon were moderate. Hazelton and Murphy [13] classified soil organic carbon percentages of $<0.60,0.6-1.0,1.0-1.80,1.80-$ 3.0 , and $>3$ as very low, low, medium, high, and very high, respectively. Therefore, the soil of all experimental sites has high organic carbon content.

Table 2. Physical and chemical properties of the soil before planting.

\begin{tabular}{|c|c|c|c|c|c|c|c|c|c|c|}
\hline \multirow{3}{*}{ Soil properties } & L1 & L2 & & & L3 & & & L4 & & \\
\hline & \multicolumn{10}{|c|}{ Duration } \\
\hline & 2017 & 2017 & 2018 & 2019 & 2017 & 2018 & 2019 & 2017 & 2018 & 2019 \\
\hline $\mathrm{pH} \mathrm{H}_{2} \mathrm{O} 1: 2.5$ & 7.1 & 6 & 5.73 & 6.4 & 6.1 & 6.59 & 5.54 & 5.9 & 5.96 & 5.78 \\
\hline $\mathrm{TN}(\%)$ & 0.26 & 0.27 & 9.29 & 0.31 & 0.26 & 52.32 & 0.23 & 0.27 & 89.42 & 0.3 \\
\hline av.P $\mathrm{mg} \mathrm{kg}^{-1}$ of soil & 14.56 & 13.32 & 0.21 & 17.44 & 11.66 & 0.27 & 6.41 & 24.96 & 0.25 & 13.82 \\
\hline av.K mg kg${ }^{-1}$ of soil & 67.5 & 66.4 & - & - & 68.72 & - & - & 64.15 & - & - \\
\hline OC (\%) & 4.45 & 5.52 & - & - & 3.27 & - & & 8.53 & - & - \\
\hline OM (\%) & 7.67 & 9.51 & - & - & 5.64 & - & & 14.7 & - & - \\
\hline Clay (\%) & 46 & 42 & - & 53.33 & 30 & - & 58.67 & 40 & - & 58 \\
\hline Silt (\%) & 34 & 26 & - & 26.67 & 30 & - & 28.67 & 32 & - & 27.33 \\
\hline Sandy (\%) & 20 & 32 & - & 20 & 40 & - & 12.67 & 28 & - & 14.67 \\
\hline Textural class & clay & clay & - & Clay & clay loam & - & Clay & clay & - & Clay \\
\hline
\end{tabular}

$\mathrm{L} 1=$ location one, $\mathrm{L} 2=$ location two, $\mathrm{L} 3=$ location three and $\mathrm{L} 4=$ location four, missed values was not reported

Plant height and thousand grain weight were not significantly $(\mathrm{p}>0.05)$ affected by the fertilizer application. The fertilizer treatments was significantly $(\mathrm{P}<0.05)$ affected the number of ear per plant, ear length and grain yield. The maximum number of ear per plant (1.26) was recorded from the application of $92 \mathrm{~N}+30 \mathrm{P} \mathrm{kg} \mathrm{ha}^{-1}$, while the minimum number ear per plant (1.01) from the control treatment (Table 3).

The maximum ear length $(17.76 \mathrm{~cm})$ was recorded from the application of $92 \mathrm{~N}+30 \mathrm{P} \mathrm{kg} \mathrm{ha}^{-1}$, while the minimum ear length $(15.15 \mathrm{~cm})$ from the control treatment. An increase in ear length at higher $\mathrm{N}$ and $\mathrm{P}$ could be due to good photoassimilates supply which facilitates photosynthesis. Increase in photosynthesis activities account for growth under an adequate supply of nitrogen and phosphorus [14]. The maximum assimilates supply should be available during maize grain filling with a split application of nitrogen [Arif]. Moraditochaee et al. [15] reported that increasing the nitrogen level from 50 to $200 \mathrm{~kg} \mathrm{ha}^{-1}$ significantly increased the ear length of maize from 10.17 to $15.69 \mathrm{~cm}$.

The result obtained from this study showed that different application rates of nitrogen and phosphorus fertilizers significantly improved maize grain yield. Application of 92 $\mathrm{kg} \mathrm{N} \mathrm{ha}{ }^{-1}+30 \mathrm{~kg} \mathrm{P} \mathrm{ha}^{-1}$ fertilizer was significantly $(\mathrm{p}<0.05)$ affect number of ear per plant, ear length and grain yield (Table 3). This was followed by $64 \mathrm{Kg} \mathrm{N} \mathrm{ha}^{-1}+20 \mathrm{~kg} \mathrm{P} \mathrm{ha}^{-1}$ (blanket application) and the lowest grain yield was recorded from control treatment (no fertilization). 
This result agree with the finding of Sheferaw et al. [4] who found that maximum grain yield of maize was attained with the application of $92 \mathrm{~kg} \mathrm{~N} \mathrm{ha}^{-1}$ and $40 \mathrm{~kg} \mathrm{P} \mathrm{ha}^{-1}$ in Yeki District at Teppi Southwest of Ethiopia. Application of NP fertilizer significantly influences plant height, number of ear per plant, ear length, grain yield and above dry biomass of maize [16]. Ali et al. [17] reported combined application of nitrogen and phosphorous increase maize yield by $112.05 \%$ as compared to the control plot. An application of NPK increase grain yield, dry matter and $\mathrm{N}$ uptake of maize [18] and $60 \mathrm{~kg} \mathrm{P} \mathrm{ha}^{-1}$ of increases maize grain yield and improved P nutrient uptake [19].

Table 3. Effect of Nitrogen and Phosphorus rates on the yield and yield components of maize overall three year (2017-2019) in Yeki District.

\begin{tabular}{|c|c|c|c|c|c|}
\hline $\begin{array}{l}\text { Treatments (Fertilizer kg } \\
\mathrm{ha}^{-1} \text { ) }\end{array}$ & Plant height $\mathrm{cm}$ & $\begin{array}{l}\text { Number of ear per } \\
\text { plant }\end{array}$ & Ear length $\mathrm{cm}$ & $\begin{array}{l}\text { Thousand seed weight } \\
\text { gm }\end{array}$ & Grain yield $\mathrm{kg} \mathrm{ha}^{-1}$ \\
\hline Control & 246.05 & $1.01^{\mathrm{c}}$ & $15.15^{\mathrm{c}}$ & 337.97 & $7706.3^{b}$ \\
\hline $64 \mathrm{~N}+46 \mathrm{P}_{2} \mathrm{O}_{5}$ & 253.62 & $1.14^{\mathrm{b}}$ & $16.45^{\mathrm{b}}$ & 325.25 & $8747.9^{\mathrm{ab}}$ \\
\hline $92 \mathrm{~N}+69 \mathrm{P}_{2} \mathrm{O}_{5}$ & 259.24 & $1.26^{\mathrm{a}}$ & $17.76^{\mathrm{a}}$ & 342.69 & $10052.9^{\mathrm{a}}$ \\
\hline LSD & ns & 0.055 & 0.72 & ns & 1461.2 \\
\hline CV (\%) & 17.58 & 5.75 & 5.24 & 6.68 & 19.77 \\
\hline
\end{tabular}

LSD $=$ List significant difference at $\mathrm{p}<0.05, \mathrm{CV} \%=$ coefficient variation, Means with the same letter are not significantly different

Economic analysis was performed to investigate the economic feasibility of the treatments (fertilizer rate). Partial budget is a method of organizing experimental data and information about the costs and benefits of various alternative treatments. Marginal analysis is a method for comparing the costs that vary with the net benefits for selecting the best technology for recommendations from the experiment.

Partial budget averaged of the three (3) treatment calculated from income and expenses based on variable cost (Table 4). Net benefit calculated by subtracting the Total Variable Cost (TVC) from the gross field benefit (GFB) for each treatment. All variable costs calculated excluding the price of other agronomic practices such as cost of seed, land plowing, sowing, weeding, protection of the farm and harvesting because it was uniform for all treatments. Cost of fertilizer TSP was Ethiopian birr (ETB $13.75 \mathrm{~kg}^{-1}$ and urea was ETB $\left.11 \mathrm{~kg}^{-1}\right)$. The cost of fertilizer transportation considered as ETB 20 per $100 \mathrm{~kg}$ fertilizer and labor cost of fertilizer application ETB 27 per day for 8 hours for $100 \mathrm{~kg}$ fertilizer. The Local market-selling price of one-kilogram of maize in Ethiopia birr at the Teppi area was five birr. The variable costs were summed up and subtracted from gross field benefits, which taken as net benefit. The average yield adjusted downward by $10 \%$ and used to reflect the difference between the experimental field and the expected yield from farmers' fields with farmers' practices from the same treatments [20]. Dominance analysis led to the selection of treatments ranked in increasing order of total variable costs. For each pair of ranked treatments, the percent marginal rate of return (MRR) was calculated. The MRR (\%) between any pair of un-dominated treatments was the return per unit of investment in fertilizer. It calculated by dividing the change in net benefit to the change in variable costs. Analysis of marginal rate of return (MRR) carried out for non-dominated treatments and the MRRs compared to a minimum acceptable rate of return (MARR) of $100 \%$ to select the optimum treatment [21].

The highest net benefit of $41042.55 \mathrm{ETB} \mathrm{ha}^{-1}$ was obtained from the application of $92 \mathrm{~kg} \mathrm{~N} \mathrm{ha}^{-1}+69 \mathrm{~kg} \mathrm{P}_{2} \mathrm{O}_{5}$. On the other hand, the lowest net benefit (34678.35 ETB ha ${ }^{-1}$ ) was obtained from control plot.

Table 4. Partial budget and marginal analysis of fertilizer verification on maize in Yeki district.

\begin{tabular}{|c|c|c|c|c|c|c|}
\hline Treatments (Fertilizer kg ha ${ }^{-1}$ ) & $\begin{array}{l}\text { Grain yield kg } \\
\mathrm{ha}^{-1}\end{array}$ & $\begin{array}{l}\text { Adjusted grain down } \\
\text { to } 10 \%\end{array}$ & GFB & TVC & NB & MRR\% \\
\hline Control & 7706.3 & 6935.67 & 34678.35 & 0 & 34678.35 & \\
\hline $64 \mathrm{~N}+46 \mathrm{P}_{2} \mathrm{O}_{5}$ & 8747.9 & 7873.11 & 39365.55 & 3142.5 & 36223.05 & 49.15 \\
\hline $92 \mathrm{~N}+69 \mathrm{P}_{2} \mathrm{O}_{5}$ & 10052.9 & 9047.61 & 45238.05 & 4195.5 & 41042.55 & 457.69 \\
\hline
\end{tabular}

$\mathrm{GFB}=$ growth field benefit, $\mathrm{TVC}=$ total variable cost and $\mathrm{MRR}=$ marginal rate of return

\section{Conclusion}

Applications of NP fertilizer rate were significantly affect yield and yield component of maize. The highest maize grain yield $\left(10052.9 \mathrm{~kg} \mathrm{ha}^{-1}\right)$ and the lowest $\left(7706.3 \mathrm{~kg} \mathrm{ha}^{-1}\right)$ were obtained from the application of $92 \mathrm{~kg} \mathrm{~N}^{-1}$ with $69 \mathrm{~kg} \mathrm{P}_{2} \mathrm{O}_{5}$ $\mathrm{ha}^{-1}$ and control plot respectively. Also the highest number of ear per plant (1.26) and the lowest (1.01) were obtained from the application of $92 \mathrm{~kg} \mathrm{~N} h a^{-1}$ with $69 \mathrm{~kg} \mathrm{P}_{2} \mathrm{O}_{5} \mathrm{ha}^{-1}$ and control plot respectively. Application of $92 \mathrm{~kg} \mathrm{~N} \mathrm{ha}^{-1}$ with $69 \mathrm{~kg} \mathrm{P}_{2} \mathrm{O}_{5} \mathrm{ha}^{-1}$ gave the highest net return of EB 41042.55 with highest marginal rate of return of $457.69 \%$. Application of $92 \mathrm{~kg} \mathrm{~N} \mathrm{ha}^{-1}$ with $69 \mathrm{~kg} \mathrm{P}_{2} \mathrm{O}_{5}$ ha $^{-1}$ was improved maize grain yield by $30.45 \%$ and $14.92 \%$ as compared to the control plot and blanket recommended fertilizer application and also economically feasible. Therefore; application of $92 \mathrm{~kg} \mathrm{~N}$ ha $^{-1}$ with $69 \mathrm{~kg} \mathrm{P}_{2} \mathrm{O}_{5}$ $\mathrm{ha}^{-1}$ were recommended for maize production in Yeki District and similar agro-ecologies of Southwest of Ethiopia. This result is basic to further determination of the balanced fertilizer application rate for maize in Yeki district. 


\section{Acknowledgements}

We would like to thanks to Teppi Agricultural Research Center for facilitating the experiment. Very special thanks to Mr. Tesfaney Ejegu for his support in field experiment to completion.

\section{References}

[1] Wondwosen, T and Sheleme, B. 2011. Identification of growth-limiting nutrient (s) in Alfisols: soil physicochemical properties, Nutrient Concentration and Biomass Yield of Maize. American Journal of Plant nutrient and fertilizer technology. 2011; 1 (1): 23-35.

[2] Zingore, S. 2011. Maize productivity and response to fertilizer use as affected by soil fertility variability, manure application, and cropping system, Better crops, 95 (1): pp. 4-6.

[3] ATA (Agricultural Transformation Agency). 2016. Soil fertility status and fertilizer recommendation atlas for SNNPRS, Ethiopia. Ethiopian Agricultural Transformation Agency (ATA), A. A, Ethiopia.

[4] Shiferaw, T, Argaw, A. and Balemi, T. 2018. The response of hybrid maize (Zea mays) to $\mathrm{N}$ and $\mathrm{P}$ fertilizers on nitisols of Yeki District, Sheka Zone. Ethiopian Journal of Agricultural Sciences, 28 (2), pp. 53-64.

[5] Wakene, N., Tolera, A., Minale, L., Tolessa, D., Tenaw, W., Assefa, M. and Zirihun, A. 2011. Soil fertility management technologies for sustainable maize production in Ethiopia. In meeting the challenges of global climate change and food security through innovative maize research: pp. 123-127.

[6] Tolessa, D, Gemechu, G and Melakeselam, L. 1994. Response of maize to split application of nitrogen fertilizer at Bako. In 6 Annual Conference of the Crop Science Society of Ethiopia. Addis Abeba (Ethiopia). 3-4 May 1994.

[7] Ali, R. and Raouf, S. S. 2012. Effects of rates and nitrogen application timing on yield, agronomic characteristics and nitrogen use efficiency in corn. International Journal of Agriculture and Crop Sciences, 9: 534-539.

[8] Walkley, A. and Black, I. A. 1934. An examination of the Degtjareff method for determining soil organic matter, and a proposed modification of the chromic acid titration method. Soil science, 37 (1): pp. 29-38.

[9] Bremner, J. M. 1965. Total Nitrogen, methods of soil analysis, part 2: chemical and microbiological properties (methods of soilanb), pp. 1149-1178.
[10] Landon J. R. 1991. Booker Tropical soil manual, a handbook for soil survey and agricultural land evaluation in the tropics and subtropics. Longman, Booker. 474p.

[11] Tekalign, M. and Haque, I., 1991. Phosphorus status of some Ethiopian soils. III. Evaluation of soil test methods for available phosphorus. Trop. Agric, 68, pp. 51-56.

[12] Horneck, D. A., Sullivan, D. M., Owen, J. S and Hart, J. M. 2011. Soil test interpretation guide.

[13] Hazelton, P. and Murphy, B. 2007. Interpreting soil test results: what do all the numbers mean 2nd (ed). Department of natural resources. CSIRO publishing. Australia. Pp. 77-79.

[14] Jan, A, Naveed, K., and Jan, T., 2002. Residual effect of groundnut and soil amendments on the Performance of gram under rainfed conditions. Asian Journal of plant science, 1 (6): 625-627.

[15] Moraditochaee, M., Motamed, M. K., Azarpour, E., Danesh, R. K and Bozorgi, H. R. 2012. Effects of nitrogen fertilizer and plant density management in corn farming. ARPN Journal of Agricultural and Biological Science, 7 (2): pp. 133-137.

[16] Gurmu, S., 2020. Determination of NP Fertilizer Rates and Plant Population Density on Yield and Yield Related Parameters of Quality Protein Maize (Zea mays L.) in Southwestern Ethiopia.

[17] Ali. J, Bakht. J, Shafi. M., Khan, S and Sha, W. A. 2002. Effect of various levels of $\mathrm{N}$ and $\mathrm{P}$ on yield and yield components of Maize. Pakistan Journal of Agronomy, 1 (1): pp. 12-14.

[18] Adu-Gyamfi, R., Agyin-Birikorang, S., Tindjina, I., Manu, Y. and Singh, U., 2019. Minimizing nutrient leaching from maize production systems in northern Ghana with one-time application of multi-nutrient fertilizer briquettes. Science of The Total Environment, 694, p. 133667.

[19] Wang, X., Liu, S., Yin, X., Bellaloui, N., Winings, J. H., Agyin-Birikorang, S., Singh, U., Sanabria, J. and Mengistu, A., 2020. Maize Grain Composition with Additions of NPK Briquette and Organically Enhanced N Fertilizer. Agronomy, $10(6)$, p. 852.

[20] Getachew, A and Rezene, F. 2006. Response of faba bean to phosphate fertilizer and weed control on nitisols of Ethiopian highlands. Italian Journal of Agronomy, pp. 281-290.

[21] CIMMYT. 1998. Economics Program, International Maize and Wheat Improvement Center, from agronomic data to farmer recommendations: an economics training manual (No. 27). 